\title{
NEW CONCEPT OF IGNORANCE: \\ AN ISLAMIC EPISTEMOLOGICAL APPROACH TO THE STORY OF MOSES AS RELEVANT REFERENCE FOR CONTEMPORARY ULAMA
}

\section{D.I. Ansusa Putra}

Universitas Islam Negeri (UIN) Sulthan Thaha Saifuddin Jambi

e-mail:ansusa@uinjambi.ac.id

\author{
Submission: 25 October 2019 \\ Revised: 30 November 2019 \\ Published: 8 December 2019
}

\begin{abstract}
The understanding of knowledge in the Islamic literature is more focus on the conception of knowledge itself, such as the epistemology of ma'rifah al-Ghazali, the epistemology of Islamic science Syed Nuqaib al-Attas, and the epistemology of the Qur'an Fazlur Rahman. This article is different from the previous concept that looks at knowledge from its antonym, Ignorance (Jabiliyyah). Ignorance is the important topic of socio-religious in the Qur'an which creates new understanding in Islamic epistemological construction. This article argues that in the Qur'an antonimical perspective, Ignorance is the antonym of the word "Islam". Here, Islam has not only seen as a religious institution. Islam is the knowledge itself which full of goodness and good perspective. While Ignorance is the absence of knowledge which at the same time as a source of everything contrary to Islam as knowledge. This statement would affect the epistemological construction of science as a whole and creates a new concept in seeing Islam and everything related to it. This article analyzes the verses of the Moses story in the Qur'an through what author call the antonymy interpretation method. It mean, interpreting the Qur'an about the knowledge through the antonym of the knowledge itself, that is nescience, ignorance and idiocy. The results of this study do not emplace the ulama as guardians of religious authority as understood today, but the ulama are groups of people who have capabilities in the structuring of Islam as knowledge.
\end{abstract}

Keywords: Concept of ignorance, Epistemology of the Qur'an, Contemporary ulama.

\section{Abstrak}

Pemahaman pengetahuan dalam khazanah Islam lebih menitikberatkan pada konsepsi pengetahuan itu sendiri, seperti epistemologi ma'rifah al-Ghazali, epistemologi keilmuan Islam Syed Nuqaib al-Attas, dan epistemologi al-Qur'an Fazlur Rahman. Berbeda dari sebelumnya, artikel ini melihat pengetabuan dari antonimnya yaitu Ignorance (Jabiliyyah). Ignorance merupakan topic sosio-religi penting dalam the al-Qur'an yang melabirkan pemahaman baru dalam bangunan epistemologi Islam. Artikel ini berargumen babwa dalam perspektif antonimimitas al-Qur'an, Ignorance adalah antonym dari kata Islam. Di sini, Islam tidak hanya dipandang sebagai institusi agama. Islam adalah pengetabuan itu sendiri yang penub kebaikan dan cara pandang yang baik. Sebaliknya, Ignorance merupakan ketiadaan pengetahuan yang di saat yang sama merupakan sumber dari segala perilaku yang bertentangan dengan Islam pengetahuan. Pernyataan ini akan mempengarubi bangunan epistemologi ilmu secara keseluruban dan melabirkan konsep baru dalam melibat Islam dan segala yang berbubungan dengannya. Artikel ini menganalisis ayat-ayat kisab Musa melalui sebuab metode penafsiran lawan kata atau yang penulis sebut sebagai metode penafsiran antonimi. Artinya, menafsirkan al-Qur'an mengenai pengetabuan melalui lawan kata dari pengetabuan itu, yaitu ketidaktahuan, ignoran dan kebodohan. Hasil penelitian ini tidak menempatkan ulama sebagai penjaga otoritas agama sebagaimana yang dipahami saat ini, tetapi ulama adalah kelompok masyarakat yang punya kapabilitas dalam strukturalisasi Islam sebagai pengetahuan.

Kata Kunci: Konsep ignoran, Epistemologi al-Qur'an, Ulama kontemporer.

\section{Background}

Contemporary everyday-life Muslim indicates the confusion of the Muslim thought. The development of new media has made a major contribution to world civilization. However, on the other hand, advances of the new media technology are use negatively by political and economic interests. One of the negative sides of media technology today is the post-truth phenomenon. Posttruth as a social phenomenon describes intellectual confusion around the muslim 
world. Post-truth means the manipulation of reality by forming something that does not exist as if it were made, real and true ${ }^{1}$. This makes Muslim society no longer distinguish between right and wrong, good and bad, haqq and bathil, both of them mixed up. So the people get swept up in trivial debates that are not useful. Sometimes the ulama blurted out unnecessary stupid words. Thus, Ulama as knowledgeable people and heirs of the prophets (waratsatul anbiya) become part of the problem itself. Like the phenomenon of Aksi Bela Islam that discussed massively manner in the media and the reality of Muslim societies. In this action, the ulama see themselves as authoritative sources in terms of religious propaganda ${ }^{2}$. This view is not acceptable in Islamic epistemology because this action is related to practical political interests.

Author identify this problem was caused by Muslims and Ulama understanding. They are not fully understood to the Islamic epistemology offered in the Qur'an. Muslims and Ulama see Islam only as a religious institution. Thus, at this point, the ulama were only positioned as guardians of religious purity and authority. So that Ulama become very exclusive or very resistant. Therefore, it is necessary to see and redefine Islam from an epistemological perspective so that it can be understood more thoroughly and comprehensively. Because developing Islamic paradigm must be built from the most basic study, that is epistemology field.

Epistemology is a branch of philosophy which contains a basic question that is related to habits, boundaries and sources of

${ }^{1}$ Ulya Ulya, 'Post-Truth, Hoax, dan Religiusitas di Media Sosial', Fikrah, $6.2 \quad$ (2018) 283 <https://doi.org/10.21043/fikrah.v6i2.4070>.

2 Muzayyin Ahyar and Alfitri Alfitri, 'Aksi Bela Islam: Islamic Clicktivism and the New Authority of Religious Propaganda in the Millennial Age in Indonesia', Indonesian Journal of Islam and Muslim Societies, 9. 1 (2019), $1-29$ <https://doi.org/10.18326/ijims.v9i1.1-29>. knowledge. Historically, philosophers have offered how to know something ${ }^{3}$.

Since epistemology field defines toward all Islamic terminologies, Many experts emerge to develop Islamic epistemology from classical to modern. In the classical era, there has been a famous name like Al-Ghazali who defined Islam in tasawuf perspective. Al-Ghazali had great contribution in formulating the sources of knowledge/science in Islam. The big contribution from Al-Ghazali was used by Muslim thinker in the future. For instance the science's categorization of Abid Al-Jabiri: Bayani, Burhani, and Irfani which was affected by the ideas of Islamic scientific sources according to Al-Ghazali ${ }^{4}$. In modern era there was thinker who offered an Islamic reading with the grand design that was called as Islamic scientific epistemology of Syed Nuqaib Al-Attas. The conception of Al-Attas Scientific Islamization had a great contribution in giving an applicative and operative concept of Islamic science in human life. ${ }^{5}$ In the modern era there was also a new paradigm in viewing Islam with the Qur'an epistemology instrument of Fazlur Rahman. In his work etico religious, Islam and the major themes of the Qur'an, Rahman offered epistemology of the Qur'an about the contextualization and the relevance of the Qur'an with the reality ${ }^{6}$. Its big concept about the contextualization of verse led a world view which was very operative and applicative for contemporary

${ }^{3}$ Rik Peels and Martijn Blaauw, 'The Epistemic Dimensions of Ignorance', in The Epistemic Dimensions of Ignorance (New York: Oxford University Press, 2016), p. 1-217 <https://doi.org/10.1017/9780511820076>.

${ }^{4}$ M. Faisol, 'Struktur Nalar Arab-Islam Menurut Abid Al-Jabiri', Tsaqafah, 6.2 (2010), 335 <https://doi.org/10.21111/tsaqafah.v6i2.124>.

5 Dinar Dewi Kania, 'Konsep Virtue Ethics dalam Pemikiran Syed Muhammad Naquib Al-Attas dan Tantangan Postmodernisme', Tasfyah, 1. 2 (2017), 157 <https://doi.org/10.21111/tasfiyah.v1i2.1850>.

${ }^{6}$ Suarni, 'Pembaharuan Pemikiran Keagamaan: Studi terhadap Pemikiran Keagamaan Fazlur Rahman', Substantia, 18.1 (2016), 206. 
ulama in supporting their duties to deliver the knowledge to society.

Author offer a concept of knowledge that is based on its antonym, ignorance (Jabiliyyab). According to the Oxford Dictionary of Islam, Jahiliyyah is translated as ignorance ${ }^{7}$. Jabiliyyah in Islamic literature is understood as the PreIslamic period, some figures such as Abul A'la al-Maududi and Sayyid Qutb understand Ignorance as a rejection of monotheism and divine law. In the current context, both of them refers to ignorance to secular modernity. for example in the work of Abu al-Ala Mawdudi, who viewed modernity as the "new jabiliyyah." Sayyid Qutb interpreted jabiliyyah as the domination of humans over humans rather than submission of humans to $\mathrm{God}^{8}$. The term denotes any government system, ideology, or institution based on values other than those referring to God. To correct this situation, such thinkers propose the implementation of Islamic law, values, and principles. Radical groups justify militant actions against secular regimes in terms of jihad against jabiliyyah ${ }^{9}$.

These three influential thinkers in Islam discussed a very different side to ignorance. Ignorance in this study is viewed from the epistemological aspects of the Qur'an. This paper does not only consider ignorance because it was few discussed ignorance structure $^{10}$. However, Author see ignorance has a significant effect as well in generating knowledge, epistemic credibility, and social injustice.

7 Tim, 'The Oxford Dictionary of Islam', Choice Reviews Online, (UK: Oxford University Press, 2004), p. 234 <https://doi.org/10.5860/choice.41-2574>.

8 Sayed Khatab, The Political Thought of Sayyid Qutb: The Theory of Jabiliyyah (Cairo: al-Maktabah, 2006), p. $21<$ https://doi.org/10.4324/9780203086438>.

9 Mohamad Kamil Hj Ab Majid, 'Masyarakat Jahiliyyah vs Masyarakat Islam', Al-Bayan Journal of alOuran \& al-Hadith, 16. 1 (2004), 18-30 <https://doi.org/10.1017/CBO9781107415324.004>.

10 Owen Flanagan, 'Virtue and Ignorance', The Journal of Philosophy, 87.88 (1990), 420<https://doi.org/10.2307/2026736>.
The emerging of ignorance epistemology will examine the complexity of the ignorance phenomena, which has an effort to identify the different expression when ignoring and examining how such ignorance has been produced and continued and its role in practising knowledge. Whereas the concept of ignorance in Islam would affect the construction of Islamic epistemology as a whole.

Author identified that one of the ways to understand the epistemology of the Qur'an about ignorance concept is the story of Moses. It is because the story of Moses in the Qur'an contained behaviours contrary to Islam that originated from ignorance. Ignorance behaviour of Fir'aun and Bani Israil would clarify how the Qur'an formed ignorance concept that is related to each other. So, it would give a general description of ignorance from epistemology perspective. In this article would discuss ignorance as one of the problems that frequently emerged in Islamic society. It would also discuss that ignorance is not only seen as behaviour but also society's perspective about all realities. As for the perspective was termed with epistemology in the study of philosophy so, this article would discuss the new concept of ignorance based on the Qur'an perspective in its explanation about the story of Moses.

Although many scholars has observed the existence of the story of Moses, Bani Israel and Fir'aun in the Qur'an with various perspectives. However, no one observed the story of Moses as a story which gave contributions in Islamic epistemology as a whole. So the result of the scholar's studies is still partial and atomistic. The story of Moses, Fir'aun and Israel was seen as epistemology that separated into some main ideas of Islamic lesson.

Julian Obermann in his article Koran and Agada: The Events at Mount Sinai said the observation of the story of Moses in the 
Qur'an is focused to criticize Jews who refused the prophecy of Muhammad ${ }^{11}$. Obermann made a misunderstanding assumption and claim. This understanding caused scepticism toward whole discourses about Islam and Jews. As if Islam did resistance toward Jews which began from The Qur'an text thus affecting the attitude of the world's Muslim religiosity ${ }^{12}$.

Efendi in Historisitas Kisah Fir'aun dalam Pespektif Islam (Historicity of Fir'un Story in Islamic Perspective) mentioned that Fir'aun in The Qur'an was described as despotic leader thus the resistance done by Fir'aun was the fight against tyranny. Whereas Bani Israel was categorized as mustadb'afin (weak community) thus Moses's mission in bringing Bani Israil was a mission to self-saving from tyranny. This view is indeed right but it is not based on the understanding of Islamic epistemology which is comprehensive thus it is very partial in understanding the context and historicity of the Qur'an ${ }^{13}$.

Syukron Affani in his work Rekonstruksi Kisah Nabi Moses dalam The Qur'an: Studi Perbandingan dengan Perjanjian Lama (The Reconstruction of Moses Prophet Story in the Qur'an: Comparative Study with Old Testament) only observed the chronological reconstruction of the story of Moses in The Qur'an and Old Testament. This study is a conclusion that the story of Moses in the Qur'an is more difficult to be reconstructed than the story of Moses in Old Testament ${ }^{14}$.

11 Julian Obermann, 'Koran and Agada: The Events at Mount Sinai', The American Journal of Semitic Languages and Literatures, 58. 1 (1941), 23-48 <https://doi.org/10.1086/370587>.

12 Ismatu Ropi, 'Al-Yahūd fì Mu'allafāt alMuslimīn bi Indonesia: Dirāsah Awwalīyah', Studia Islamika, 26.1(2019), 149-183 <https://doi.org/10.15408/sdi.v26i1.10631>.

13 Effendi, Effendi, 'Historisitas Kisah Fir'aun dalam Perspektif Islam', Al-Adyan: Jurnal Studi Lintas Agama, $\quad 13.1 \quad$ (2018), 25-43 <https://doi.org/10.24042/ajsla.v13i1.2944>.

14 Syukron Affani, 'Rekonstruksi Kisah Nabi Musa dalam al-Quran: Studi Perbandingan dengan
Not many experts who talk about ignorance in the Qur'an. Even if there is, both of them are still observed separately as if both of them are not related. Therefore, this study is very relevant to be understood by Ulama in seeing Contemporary Islam phenomena. This study analyzed words that frequently emerged in the story of Moses and composed their meaning by using antonym analysis. Ignorance behaviours were analyzed to build definition and ignorance epistemology which were the antonym of Islam as knowledge.

\section{Offering Antonimy Interpretation Methods}

The antonymy method as a framework for interpreting the Qur'an is a new method for understanding the Qur'an. As we know, since the Qur'an revealed many methods have emerged to understand its implicit message. The most commonly used methods are: tablili method, ijmali method, comparative method and thematic method ${ }^{15}$. The method of interpretation means the methods that use to interpret the Qur'an ${ }^{16}$. So, from this general understanding it can be defined that the Antonimy interpretation method is the ways and steps uses to interpret the Qur'an with linguistic features based on antonymity analysis (the opposite of words).

Today's contemporary methods of interpretation are dominated by social, cultural and contextual approaches ${ }^{17}$. Some figures such as Fazlur Rahman with his double movements, shahrur with budud theory, Hasan Hanafi action texts, etc. have made intellectual contributions to Muslims in the face of social

Perjanjian Lama', Al-Ibkam: Jurnal Hukum \& Pranata Sosial, 12.1 (2017), 123 <https://doi.org/10.19105/alihkam.v12i1.1259>.

${ }^{15}$ Muhammad Yunan Yusuf, 'Metode Penafsiran al-Qur'an', Syamil, 2.1 (2014), 11.

16 Sanaky Hujair A H, 'Metode Tafsir [ Perkembangan Metode Tafsir Mengikuti Warna atau Corak Mufassirin ]', Al-Mawarid, 12.1 (2008), 1-12.

17 Abdul Mustaqim, 'Epistemologi Tafsir Kontemporer: Studi Komparatif antara Fazlur Rahman dan Muhammad Syahrur' \{unpublished doctoral thesis, UIN Sunan Kalijaga, Yogyakarta, 2007\}, p. 12. 
change ${ }^{18}$. At this point, Author agree with the Islamic scholar, that the results of interpretation must be aimed at improving the quality of Muslim societies. Because the Qur'an descends as a human guide from ignorance to knowledge both on an individual and collective level.

Although this method has just been introduced, some of the steps of its application still refer to established methods. This method uses the identification of verses based on themes ${ }^{19}$. This is the first step in this method. Collecting verses based on themes can be done through the classification of verses with the same content. In this case, the verses of the Moses story are traced through figures related to the Moses story: Moses and Harun, Fir'aun, Bani Israil. The classification of this verse is very important as a first step in understanding the verses that are sometimes scattered in various surahs of the Qur'an.

While the second step is the analysis. This method is a continuation of the theory of Asinonymity. Author see the analysis of previous language interpretations still needs to be developed. The analysis of language interpretation is the theory of the asinonymity of lafaz al Qur'an which has been used by many modern mufassir. This theory was developed by A'isyah bint Abdurrahaman or known as Bint al-Syati', she continued the work of her husband Amin al-Khuli. Then this theory is used by Muhammad Shahrur in his interpretation ${ }^{20}$.

The linguistic style here uses linguistic such as Ilmu Dilalah (semantic), semantic is

18 Abdul Karim, 'Reformulasi Tafsir Ijtima'i dalam Menjawab Problematika Sosial', Hermeneutik, 9. 2 (2016), 419.

${ }^{19}$ Makhfud Makhfud, 'Urgensi Tafsir Maudhu`i (Kajian Metodologis)', Jurnal Pemikiran Keislaman, 27.1 (2017),

25<https://doi.org/10.33367/tribakti.v27i1.256>.

${ }^{20}$ Mia Fitriah Elkarimah, 'Kajian Asinonimitas alKitab wal al-Qur'an: Qira'ah Muashirah', Lingua: Journal of Language, Literature and Teaching, 14.2 (2017), 181 <https://doi.org/10.30957/lingua.v14i2.302>. useful to explore the field of meaning of the word that wants to interpret. In this article, after identifying the verse based on the theme; that is the stories of Moses, the word ignorance (jabiliyyah) is sought for the field of meaning from the verses that have been identified. In this case, the semantic field of ignorance in the verses of the story of Moses is: takabbur, mufsid, kufr, inkar, takdzib, musrif, zalim, and fasik. It must be ensured that there is a relationship between words and their field of meaning. Or there is a semantic relationship between meaning and direction. In this case, ignorance is shown through either Dilalah lafziyah or Dilalah ghairu lafiziah.

Author offer this method to fulfill alternative meanings of the Qur'an based on language logic. However, the logic of language must have a contribution to Muslim social intellectuals.

\section{The Story of Moses in Forming Islamic} Epistemology

One of the new perspectives offered by the Qur'an is the perspective toward previous society. No doubt, old stories have spreaded as story in the life of pre-Islamic Arab society. However, Islam came in different goal and view to those legend stories.

As in another kitab samawi, Al-Qur'an is holy book contains many stories and the history of previous people. Ulama mention almost a third of the contents of the Qur'an is stories and history ${ }^{21}$. The interesting part, from all of those stories, the story of Moses becomes the most mentioned story in the Qur'an compared to other propreths. The story of Moses is mentioned frequently in any different surah. It is almost 30 surah in The Qur'an tell about Moses ${ }^{22}$. While Moses's name has been mentioned for 136 times in the

${ }^{21}$ H. M. Amir, 'Kisah Nabi Ibrahim dalam AlQur'an dan Relevansinya dengan Pendidikan Islam', Ekspose, 23.1 (2014), 1-22.

${ }^{22}$ Hussein Husaini, Qasas al Qur'an: Muqtabas min Tafsir al-Amthal (Qum: Maktabah Anshariyan Publishing and Press, tt), p. 187. 
Qur'an ${ }^{23}$. However, there is no contradiction between one verse and another. All of them are told harmoniously in a mutually supportive naratives. Some experts argued that the story of Moses when he led Bani Israil against Fir'aun was a perfect reference to be referred by people. Moses lived in Fir'aun era which was known as a tyranical king on his era. At the same time, Moses was a leader from his people Bani Israil which was known as ignorant community. Therefore, the description of tyranny and ignorant gathered into one inseparable part. The story of Moses with Fir'aun is mentioned frequently in the Qur'an because both of them are the symbol of the truth and wrong. Fir'aun stands for ungratefulness and sleaze for denying Allah and his propeths while Moses stands for faith and truth. Moses is the prophet who receives the treatise perfectly as well directly talk to Allah without any limits. Thus this story becomes the biggest lesson for ablu iman and ablu kufur. His name is mentioned frequently in the Qur'an shows that Allah wants us to contemplate of history, the difficulties, exhaustion, disturbance he encountered and tests that came insistently ${ }^{24}$.

The Qur'an tells the story of Moses, Fir'aun and Bani Israel as epistemology or perspective of pre-Islamic society to see the truth vis a vis of new knowledge that has been brought by Muhammad. Since this perspective will bring them to get out from evil and cruelty.

How many views are there? First, the story of Moses gives us new perspective about the truth. The story of Moses frequently mentions the word of truth and its antonym (untruth) like lies and disobedience (AlHaqqah: 10, Al-Mu'minun: 48, Al-Maidah: 72). This gives a new perspective in revealing the

${ }^{23}$ Utsman Ibn Muhammad Al-Khamis, Hiqbah min al-Tarikh, Cet. I, (Cairo: Maktabah al-Islamiyah, 1999), p. 23.

${ }^{24}$ Al-Khamis. definition of truth. Truth is all words contrary to lies. The story of Moses also mentions that truth is something related to proof, reality. In epistemology of science, truth becomes important terminology to be studied. Where, this definition about the truth gives main understanding of the knowledge as whole.

The story of Moses gives a view that Islam is the absolute truth. That all of knowledge brought by Islam is information that has absolute truth about the nature of realm, personal identity and goals of all creatures, either macro or microcosmic. The Qur'an commands people to find the absolute truth as one of their existance goal. Source of truth is only achieved through revelation information. While the logical maximalization (common sense) and sensory observation is only a tool to achieve the truth.

The preposition of truth in Islam is through only revelation because of the absence of another instrument that could change the direction of knowledge except Islam. Historical fact said that after the coming of Islam with new knowledge, the world simultaneously followed the direction of that new knowledge in achieving progress, civilization, and prosperit ${ }^{25}$. It includes western civilization that actually modified Islam as knowledge adjusted to their ideology. Western civilization follows Islamic knowledge trend by modifying a little of their starting point in developing science. Like the discussion about the way to the truth (epistemology), "methodical doubt" becomes something interesting to date, especially in western scientific world. It can be seen from western admiration toward Rene Descartes effort who introduced methodical doubt in western world in Renaissance era. Even, the introduction of methodical doubt became one of causes to

25 Wallace Murphy, What Islam Did for Us: Understanding Islam's Contribution to Western Civilization (London: Watkins Publishing, 2006), p. 268. 
state Descrates as the father of modern philosophy.

The emphasis that doubt has uses in reaching truth as if determining that doubt is a legal way to reach the truth. However, this is not the case. In this position, the writer agreed with Al-Attas who gave serious critics toward the case from Islamic epistemology corner. $\mathrm{He}$ argued in Prolegomena to The Metaphysics of Islam, that there was no proof that doubt has delivered someone to the truth and no other thing. That critic had serious value if it was continously tracked. The quantity of doubt and truth as well as the relation between them showed something that was not casual. Doubt, in fact, could exceed another condition except truth and that meantt it was not the truth ${ }^{26}$. AlAttas in this case also held that science was not neutral, because science always took side to the truth and goodness ${ }^{27}$.

This argument strengthened with the reading of epistemology of the Qur'an about doubt understanding in The Qur'an. The word 'rayb' means doubt (verb) and 'syak' means hesitation (noun) does not emerge except in legitimating the truth. The Qur'an never once orders people to doubt about something in reaching the truth. The Qur'an does not use doubt as a method to reach the truth. That means, the Qur'an places doubt only to show untruth in seeing the truth itself.

This methodical doubt yields scientific consept that is called as relativistic. The sufferers of epistemological relativism assume all people and groups are all the same, all opinions (religion, streams, sects, groups, etc.) are all true, depend on each point of view.

${ }^{26}$ Syed Muhammad Naquib Al-Attas, Prolegomena to the Metaphysics of Islam (Kuala Lumpur: International Institute of Islamic Thought and Civilization, 1995), p. 25.

27 Wan Mohd Nor Wan Daud, 'Falsafah dan Amalan Pendidikan Islam', in Suatu Huraian Konsep Asli Islamisasi (Kuala Lumpur: Penerbit Universiti Malaya, 1995), p. 64.
According to this concept, truth lies and spreads everywhere, but it is relative.

Second, the story of Moses gives new perspective about badness (tyranny). Tyranny means the absence of the goodness. Words are included in lexical field of Tyranny in the story of Moses are vanity, destruction, sinners, persecuting and oppressing.

Islam encourages people collectively to have adequate knowledge before doing something or acting. Therefore, Islam as knowledge is something important in aqidah Islam $^{28}$. Since Islam as knowledge will guide people to do and act according to given knowledge. Therefore, behaviour and bad manner, like: doing tyrant, crime, lie, etc are forms of the absence of Islam as knowledge within itself. Thus, the Qur'an equalizes between people who believe (in Islam) and do good deeds in various the Qur'an verses.

Tyranny is new knowledge brought by Islam pactising aqidah and behaving. Both of them have firm relation. Tyranny in doing aqidah will drive to wrong behaviours and badness. Al-Attas discussed it in ta'dib concept. Prof. Naquib al-Attas, explained concept of manner (adab) is strongly related to the understanding of revelation (wahyu). That someone who had manner was the one who was capable to understand and place something to its place according to the dignity that has been determined by Allah ${ }^{29}$. In Islam, one who does not admit Allah as the one and only God, could be said as unfair and does not have good manner ${ }^{30}$. Because, in the Qur'an,

28 Al-Attas.

29 Syed Muhammad Naquib Al-Attas, 'Risalah untuk Kaum Muslimin', in Himpunan Risalab (Kuala Lumpur: International Institute of Islamic Thought and Civilization, 2015), p. 25.

${ }^{30}$ Full explanation of manner can be studied in Syed Muhammad Naquib Al-Attas, Risalab untuk Kaum Muslimin (Kuala Lumpur: ISTAC, 2001), 118-120. In another formula, Al-Attas defines: "Adab is recognition and acknowledgement of the reality that knowledge and being are ordered hierarchically according to their various grades and degrees of rank, and of one's proper place in relation to that reality and one's physical, 
Syirik can be state as great injustice, as it was said by Lukman to his child: "O my son, do not associate [anything] with Allah, Indeed, association [with him] is great injustice" (QS 31:13). Therefore, it is inapproriate to elevate human degree to the degre of Al-Khaliq. As it lowers the degree of Al-Khaliq to the degree of creatures is inappropriate behaviour. Knowledgeable people (Ulama) are not the same person. So do people who believe are not the same with the infidel (QS 98; QS 3:110, 119). Thus human degrees before Allah are not the same. Human degrees before Allah depend on their faith and devotion.

Such manner concept is in accordance with terminology and the goal of Islamic education itself, that is ta'dib and its goal is to build people with manner (insan adaby). Prof Naquib Al-Attas in his book, Islam and Secularism, underlined the goal of the education in Islam ${ }^{31}$.

Good man, is human who has various main values on themselves. By resting on the manners concept in Islam, thus "good man" or "man with manner", is human who know well their Good, know and love their propreths, make Prophet SAW as uswab basanah, respect ulama as the heir of the prophet, understand and put science on its respected place - understand where science that is include in fardhu ain, and where it is fardhu kifayah, where useful and desctructive science - and understand as well capable to do their duties as khalifatullah fil-ardh well ${ }^{32}$.

The third, the story of Moses gives new perspective of ungratefulness (kufr). Ungratefulness is not accepting (opposing). This understanding is similar to Imam Ja'far alShidiq understanding, Az Zubairi said that he said to Imam Jaafar as Shidiq as, "Tell me how

intellectual and spiritual capacities and potentials Syed Muhammad Naquib Al-Attas, The Concept of Education in Islam (Petaling Jaya: ABIM, 1980), p. 27.

31 Syed Muhammad Naquib al-Attas, Islam and Secularism (Kuala Lumpur: ISTAC, 2003), 150-151.

32 Al-Attas, Risalah. many types of al-kufr according to kitab Allah?" Imam Jaafar categorized ungratefulness according to kitab Allah into five types. First, ungratefulness meant rejection (and there are two types of rejection). Second, ungratefulness meant disregard for what Allah commands. Third, ungratefulness meant overturning. Fourth, ungratefulness for not being grateful (thank to Allah). Fifth, ungratefulness meant denial.

The first type, rejection ungratefulness, that is rejecting God position. It was people talks who say, There is no God (that is creator), and there is no heaven or hell. In The story of Moses, the rejection toward God existance proof was done by Fir'aun. The rejection that was done by Fir'aun related to the rejection toward proofs of The Greatness of God which based on pride and arrogance thus denying the proposition of truth that came with it. Therefore, the Qur'an stated that such ungratefulness woud not get any bidayah although it has been given the real proof (QS Al Baqarah 2: 6) $)^{33}$. This kind of ungratefulness was the most despicable type. Rejecting after getting knowledge about the truth and reality (in their hearts) although still denied it was the same as it was practiced by Fir'aun (AlHaqqah:10, al-Mu'minun: 48).

The third type from ungratefulness meaning is being ungrateful for Allah favors, like Bani Israel behaviour in The story of Moses (Al-Baqarah: 93). Allah stated so many favors given to Bani Israil, it has been frequently mentioned in many verses (AlBaqarah: 40, 47, 83, 122, 211, Al-Maidah: 70), nubuwah favor (Al-Ghafir: 53), being priviliged from another folk (Al-Jatsiah: 16). In these all verses, Allah used al-kufr word equaled to ungratefulness, showed being ungrateful and ungrateful attitude.

${ }^{33}$ Hasan Hadri, Hidayah dalam Perspektif al- Qur'an (Jambi: Sulthan Thaha Press IAIN STS Jambi, 2009), p. 33. 
The forth type of ungratefulness is disregard for what Allah commands, like in His statement, (QS Al Baqarah 2: 84-85). In this verse, Allah accused those with ungratefulness because they didn't follow Allah commands, (although it has been noted that) Allah has (in this verse) related them to faith, however He did not accept that from them and it did not give them benefit before Allah.

Fifth type of ungratefulness is denial. That is, we don't recognize you. And He said, describing demon and its attitude who denied their friends that came from human being on the Day of Resurection. Thus five types of ungratefulness according to the Qur'an as explained by Imam Jaafar as Shadiq ${ }^{34}$.

The story of Moses gives new perspective about getting lost. Getting lost means no guidance. The absence of guidance is not because of there is no explanation, proof, Allah verse in guiding people to the truth and clues. But it is caused by arrogance, ungrateful, injustice that have been in themselves, thus make their heart does not justify the real instruction conveyed. It is like Fir'aun who was lost because deceived pseudo desire power he had (Al-Qasas: 39, Al-Ankabut: 39, Al-Mu'minun: 46).

\section{Islam as Knowledge versus Ignorance}

Currently, Islam is seen as one of the continued religion from religion of samawi that have been long ago, such as Christian and Jews. Although it is assumed as true, but this view is still partial and atomistic. Islam is only seen as intitution which contains religious norms either divinity aspect, worship, and muamalah. Such view co-opts the role of Islam in wider field in human life. Therefore, no wonder so many people separate Islam from social-political life. The role of Islam is only diminished to religious aspect, halal and haram,

${ }^{34}$ Taba'taba'i. Thaba, Al-Mizan fi Tafsir al- Qur'an (Bairut: Muassasah al 'A'Lamy lil Mathbu'at, 1991), p. 185. heaven and hell, etc. On other hand, referring to Islamic epistemology source; the Qur'an, it can be obtained that Islam is not only about religious norms but further than that. Islam is giving knowledge about human perspective about idea and personal value as well its existence. Islam does not only give heaven and hell description above all something good and contains goodness. Islam is a part that can not be separated from human life. Here, Islam is not seen as religious institution in narrow meaning. Islam is perspective toward reality and world thus Islam is wider than religious routines.

Knowledge is something that can not be separated from Islam, since the word Islam itself, from basic word aslama which means "obedient", has meaning "obey to Allah's will and determination". In surah Ali Imran verse 83, Allah emphasizes that the entire contents of the universe, either in heaven and on earth, are always in Islam, means that obeying to Allah's rules. It means Islam is seen as knowledge about goodness values as well rules in it. Doing Allah's command will not be perfect without having knowledge. That's why, the word 'nature' and 'science' has the same root word : ain-lam-mim.

Islam comes to put itself as new knowledge. It offers pre-Islamic society new perspective about world, nature, and social. New perspective toward the world that worldly life is momentary. New perspective toward nature, that human and nature are the same as creature. New perspective in social that social is one aspect that is organized in Islam.

Abdul Ghaffar in Thagut dalam al-Qur'an (Thagut in the Qur'an) analyzed thagut consept that was understood as the form of tyrannical in The Qur'an from various aspects such as economy, social and politic while ignorance concept study in The Qur'an could be traced 
through Ignorance (jabiliyyah) terminology ${ }^{35}$. Studies about ignorance concept in The Qur'an have not related to tyranny and the story of Moses as it has offered to this article.

It could be concluded that, in the first period of the comig of the Qur'an, it actually aimed to embed thought to all people whom they were in idiocy, and motivated them to fulfill the emptiness with new knowledge. Therefore, the Qur'an stated with ignorance terminology that literally meant idiocy. It was different with some experts who stated that ignorance did not mean idiocy, but their arrogant act since they did not want to accept the truth.

Most experts defined knowledge with various terms, Al-Ghazali mentioned it by ma'rifah ${ }^{36}$, Al-Attas by truth ${ }^{37}$, and Fazlur Rahman as experience ${ }^{38}$. Experts' defintion about knowledge will affect their definition about ignorance. It is because ignorance always opposing with knowledge. Therefore, Al-Ghazali put ignorance in a position of inaccessibility of ma'rifat, Al-Attas put ingnorance in a position of untruth, while Rahman more put ignorance in unusefulness aspect. Thus Rahman always broght Islamic studies in usefulness, ethical, and axiological field in his most works, like etico religious, major themes of the Qur'an and Islam. Even in the major themes he wanted to connect all themes to be related to each other thus it had more intelectual usefulness. For instance, knowledge about God had urgent usefulness in seeing human existance.

35 Abdul Gaffar, 'Kontekstualitas Makna Thaghut dalam Penafsiran al-Qur'an', Tajdid, 9.2 (2015), $1-12$.

36 Amin Hasan, 'Menyusuri Hakikat Kebenaran: Kajian Epistemologi atas Konsep Intuisi dalam Tasawuf al-Ghazali', Jurnal at-Ta'dib, 7.2 (2012), 189-203.

${ }^{37}$ Wan Daud.

38 M Maraimbang, Syahrin Harahap, and Amroeni Drajat, 'Ethics of Religion According to Fazlur Rahman', Journal of Humanities and Social Science, 24.2 (2019), 73-80.
Different with those expert definitions, here the writer did not define science as ma'rifah, truth or knowledge. The writer saw knowledge was Islam and Islam was knowledge. It could be proved from The Qur'an worldview in the story of Moses.

Therefore, ignorance was the absence of the truth, goodness, acceptance and guidance. All of them boiled down to the absence of knowledge for idea and goodness value. The absence of that knowledge opposed to all knowledge for idea and goodness value that was contained in new knowledge called Islam.

In epistemological study, there are two types of ignorance: lack of knowledge and absence of true belief ${ }^{39}$.

Most of Ulama's debates about ignorance in the Qur'an are met in ignorance intepretation. However, they mostly see Ignorance as attitude and character. There is no one who sees tyranny and ignorance as perspective or epistemology of people in facing knowledge.

Islam is againt idiocy ${ }^{40}$. Because, idiocy is the source of calamity. As long as human sink down to idiocy mud, people will feel pain. And the biggest impact that happen to human beacuse of idiocy is distortion of aqidah or faith.

The word "ignorance" literally means idiocy, that is pinned to musyirikin folk before the coming of Islam is a term that summarizes all meaning of praying distortion, tyranny and disobedience toward the truth. the biggest ignorance is worshipping any other God beside Allah or syirik. It is the most dominant characteristic. Thus, the period before Prophet's coming is a period with full of idiocy called as jabiliyyah (ignorance) era.

39 Oliver Leaman, 'Islam', in The Routledge Companion to Theism (UK: Routledge Press, 2012), p. 23 <https://doi.org/10.4324/9780203123294>.

${ }^{40}$ Rajih Abd Hamid, Nazariyah al-Ma'rifah bayna al-Qur'an wa al-Filsafah (Riyadh: Maktabah Al-Muayyad, 1996), p. 75 
According to Ulama, the reference of ignorance toward the condition of Arabic nation in pre-Islamic period was full of idiocy condition about Allah, His propreth, religious syariah, being proud of nasab, arrogancy and any other distortion.

The point was ignorance was a word to all matters that opposed to Islam lesson, either great violation led to infidelity or small violation that did not lead to infidelity. All of them could be included as ignorance because all violation or matter opposed to Islamic lesson might not be sourced from science, but from idiocy. Either that violation was caused of ignorance or the domination of lust that lost faith encouragement. In The Qur'an the word of ignorance was divided into four context: first, faith context (QS. Ali Imran: 154), second, law system context (QS Al Maidah: 49-50), third, behaviour context (QS. Al Azhab: 33), fourth, character context (QS. Al-Fath: 26).

However, the variation of the word of jahala spreaded in various verses in The Qur'an with different meaning. It was registered there are 24 verses in 17 surah that mention jahala word variation ${ }^{41}$.

Actually relation conception between tyranny and ignorance in the Qur'an was in surah Al-Ahzab:73. Thus, new knowledge (Islam) that was brought in the story of Moses was antonym of ignorance that yielded any untruht forms, the absence of guidance, tyranny, and getting lost.

As for behaviour tyrants are described from verses about Fir'aun and Bani Israil as follow:

41 Luthviyah Romziana, 'Pandangan al-Qur'an tentang Makna Jâhilîyah Perspektif Semantik', Mutawatir, $\quad 4.1 \quad$ (2015), $\quad 117-138$ $<$ https://doi.org/10.15642/mutawatir.2014.4.1.117$138>$.
Table 1. Fir'aun and Bani Israil Ignorance

\begin{tabular}{|c|c|}
\hline $\begin{array}{l}\text { Fir'aun Ignorance in the } \\
\text { Qur'an }\end{array}$ & $\begin{array}{l}\text { Bani Israil Ignorance in } \\
\text { the Qur'an }\end{array}$ \\
\hline 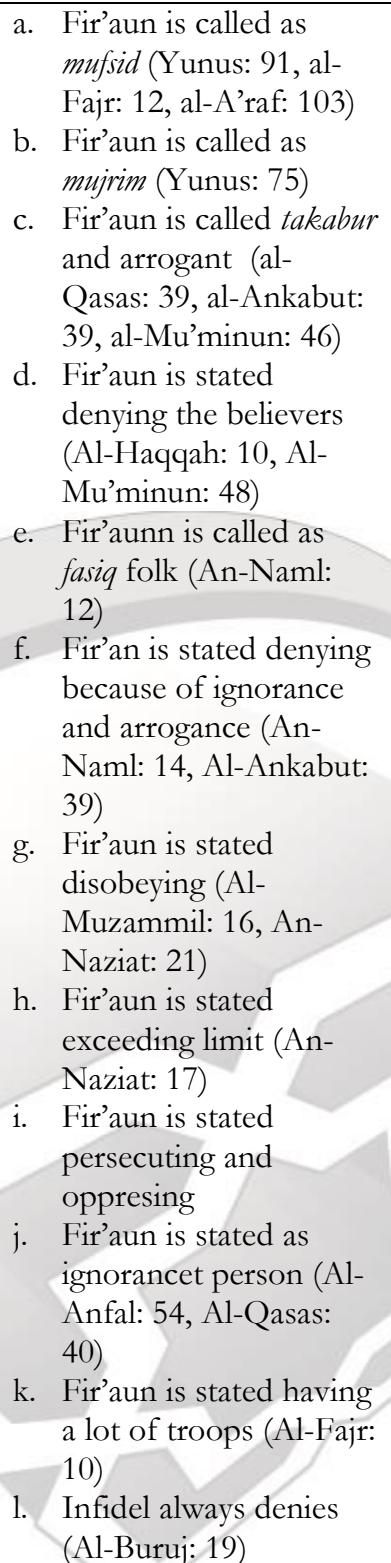 & $\begin{array}{l}\text { a. Bani Israil is } \\
\text { mentioned turning } \\
\text { away from the truth } \\
\text { b. Bani Israil is called as } \\
\text { tyrant folk (Al- } \\
\text { Baqarah: 246) } \\
\text { c. Bani Israil is stated } \\
\text { exceeding limit (Al- } \\
\text { Maidah: 32 } \\
\text { d. Bani Israil as stated as } \\
\text { denying the truth (Al- } \\
\text { Maidah: 72) } \\
\text { e. Bani Israil is stated as } \\
\text { faithless } \\
\text { exceeding limit (Al- } \\
\text { Maidah: 78) } \\
\text { Bani Israil is given } \\
\text { many privileges (Al- } \\
\text { Jathiyah: 16) } \\
\text { Bani Israil is stated } \\
\text { ungrateful (Al- } \\
\text { Baqarah: 93) }\end{array}$ \\
\hline
\end{tabular}

There were causalitative relation between ignorance and tyranny in the Qur'an that ignorancet person can lead to do tyrant, and tyrant person was basically the implementation of ignorance itself. 
The deviation of the word of 'jabala' in the story of Moses can be seen through this plot:

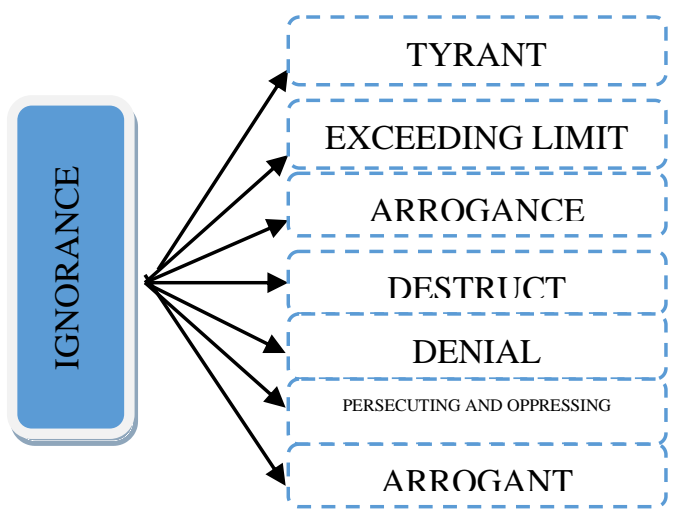

Chat 1. Ignorance in the Qur'an

\section{Knowledge Relevance Contemporary Ulama}

Talking about knowledge and science is always related to another word, that is ulama in languange perspective. Since ulama word itself is the result of derivation from Arabic languange, 'ulamā' (علماء) jama' (plural form) from 'alim (عَالِ ) that is subject form of ilm that is rooted from word $i-l-m$. Term that is known in English as knowledge. All of these terms are similar to knowledge or cleverness, and information. Louis Ma'lūf saw ilm as term referred to understanding delivery of someone toward the nature of the truth of information ${ }^{42}$.

To be a body of knowledge, Lieven Boeve has clasified basic characteristics consist of; subject of matter, method, and provisional (read: theory). These three characteristics if they were combined then they would form an accumulation known as knowledge accumulation ${ }^{43}$. Thus what it was science was the presence of problems that was studied intensively by using a scientific method, with these assumptions or theories base that have

${ }^{42}$ Louis Ma'luf, Al-Munjid fi al-Lughah wa al-A'lam (Beirut: Dar al-Masyriq, 1986), p. 654.

${ }^{43}$ Lieven Boeve, Hans Geybels, and Stijn Van den Bossche, Encountering Transcendence: Contributions to a Theology of Christian Religious Experience (UK: Peeters Publishers, 2005), p. 234. been formulated structurely, then it yielded a knowledge accumulation. In short, all knowledge that was emerged as the result of observation and research process intensively through framework and particular method with base of the presence of developing theories thus created an accumulation of knowlede that was capable to be scientifically responsible as 'ilm' in contemporary era.

The definition of knowledge above, lexically related to ulama existance. Al-Attas formulated ulama was not an expert in one field of science however he was someone who was universal in their perspectives and had authority in some science fields that were related to each other ${ }^{44}$. In short, in contemporary periode- although some experts have disagreed, science was defined as examined ability that has been formed in a body of knowledge, and the owner of the ability was called as ulama.

The word ulama itself only emerged in the Qur'an for two times. Both of them were similar to individuals with adequate knowledge $\mathrm{e}^{45}$. An interesting point from the use of this word was; that the word al-alim or alatim in singular form never referred to any other thing except God, except in Surah Yusuf; 55 that referred to the prophet of Yusuf. Of course, as it was explained by Ibn Mandzur, the word alim proposed here that was given to Yusuf was based on science that has been taught by Allah and not as alim in Allah characteristic. ${ }^{46}$ As for plural form (al'Ulama) was only mentioned twice and both of them referred to human. Here seemed the quantity of ulama seldom emerge in the Qur'an, as for its emergence more referred to the community with adequate interletuality

\footnotetext{
${ }^{44} \mathrm{Al}-$ Attas, Islam.
}

45 Imron Mustofa, 'Ulama' dan Kontestasi Pengetahuan dalam Sudut Pandang al Qur'ān', Jurnal Pendidikan Agama Islam (Journal of Islamic Education Studies), $\quad 5.1 \quad$ (2017), $\quad 68-93$ <https://doi.org/10.15642/jpai.2017.5.1.68-93>. 46 Mustofa. 
ability. For this moment, ulama could not be separated from group or community meaning with the authority of adequate knowledge.

The Qur'an led Ulama substansial toward the meaning of person who afforded to introduce radical and abstraction toward knowledge. However, there were some things which were capable to impede the process of the abstraction of this knowledge. The Qur'an states they were; kefasikan (الفسق), arrogance (الاستكبار), tyranny (الظكب), lies (الكبل), wrong doing (المعاصي), idiocy (الجهل), doubt (المِرية): ألثك ), deviation (الإنحر ) and dereliction (الغفلة). These characteristics would be toxic in the authority of science that were owned by Ulama $^{47}$. All of these became keywords that frequently mentioned to describe ignorance of Fir'aun and Bani Israil in the story of Moses.

The Qur'an as basic paradigm of the legitimation of knowledge system, needs manifestation of thought construction which acts as media or institution overshadowing its mission, value, and goal. Thus, Muslim scholars never dicotomize philosophy, social, individual matter even power with religion, or intellectuality with spirituality. All of sides respectively support to create new consept that is in accordance with philosophical and spiritual in dialectics. Therefore, ulama is seen as representative field which was born as interpretation result and implementation from nas, to implement religious command

Epistemology of the Qur'an implied in The story of Moses about ignorance has firm relevance with the function of ulama. Ulama implemented mandate to spread Islamic knowledge in each human aspect ${ }^{48}$. In ushul figh study, we obtain that ijma (Ulama consensus) is the source of the third law after The Qur'an and Hadist. It reminds that those

${ }^{47}$ Mustofa.

${ }^{48}$ Umma Farida and Abdurrohman Kasdi, 'The 2017 KUPI Congress and Indonesian Female "Ulama", Journal of Indonesian Islam, 12.2 (2018), 135-158 <https://doi.org/10.15642/jiis.2018.12.2.135-158>.
Ulama might not gather and agree to something that opposed to Islamic syariah.

In social aspect, Ulama is human support, a place to ask for suggestion and guidance. If they are absence, human will use dull people as role model, although they say something without knowledge and point to human without the right understanding. Therefore, confusion will spread in thingking and the whole of the ship will be bigger and it finaly sank. The function of ulama is as Prophet representative. Ibn Khaldun becomes the father of Sociology understand Ulama in widest context, Ulama is not only related to religious science but also as the guardian of knowledge ${ }^{49}$. The definition of ulama is parallel with the meaning of 'intellectual', scholars, or philospher.

In scientific aspect, ulama is the first reference related to the structure of Islamic knowledge, clasification, logic, as a group of knowledge references. Ibn Khaldun explained that Ulama was someone who sank themselves into idea and intellectual reflection world and did the abstraction in the meaning of seeking general patterns from straggle empiric data (umur kulliyat al-Ammah).

Ulama was authority guardian who prevented human trapped in anarchial and chaos condition. ${ }^{50}$ The absence of ulama was the beginning of the knowledge destruction and even human civilization as a whole. The losing of social control from group where, the absence of ulama drove the growing of ignorance behaviour with various forms, untruth, getting lost, tyranny, etc. Imam AlGhazali believed that the destruction of society was caused by the destruction of

49 Ibn Khaldun, Muqaddimah (Beirut: Dar AlFikr, 1973), p. 542.

${ }^{50}$ Hadri Hasan and D I Ansusa Putra, 'The 2005th Amman Message: Significant Reference for Nusantara Ulama to Enlarge the Existing Indonesian Plurality', Millati: Journal of Islamic Studies and Humanities, $3.2 \quad$ (2018), 173-188 $<$ https://doi.org/10.18326/mlt.v3i2.173-188>. 
leader. Leader destruction was caused by ulama destructun, and ulama destruction was caused by loving wealth and position. Knowledge that was owned by world ambition would not be able to organize society so there would be destruction ${ }^{51}$.

The story of Moses reflected the function of ulama in knowledge and human civilization as a whole. Moses was described as knowledge authority guardian about the view toward the world and its orientation. Knowledge showed absolute truth about human position either macro or micro cosmic. Moses was also positioned as social controller so untruth, lost, and tyrants did not spread.

\section{Conclusion}

The analysis of the story of Moses through the antonym interpretation method show us how the construction of ignorance meaning which is the antonym of the word Islam. Islam is knowledge, while ignorance is nescience that caused untruth, getting lost, tyranny, and ungratefulness. It could be seen from a new perspective about it.

Islam as knowledge-oriented to the truth. The story of Moses mentions the lexical field of truth and its antonym (untruth) like lies, rebellious (al-Haqqah: 10, al-Mu'minun: 48, alMaidah: 72). It gave a new perspective to reveal the definition of truth. That truth was all antonym of the word lies.

The story of Moses gives new perspectives about ignorance. Ignorance is the absence of goodness. The story of Moses gives a new perspective of on ungratefulness. Ungratefulness is not accepting (opposing). The story of Moses frequently mentions ungratefulness done by Fir'aun and Bani Israel. Although both of them acted as the different position in the story of Moses, both of them to be ungrateful that is caused by the absence of Islam in themselves. The story of

\footnotetext{
51 Khaldun.
}

Moses gives a new perspective about getting lost. Getting lost in the absence of guidance.

Thus according to Islamic epistemology, ignorance is the absence of Islam that made someone to reject the truth, to be ungrateful, tyrannical and lost. It emphasized that ignorance was the antonym of the word Islam. Islam is seen as new knowledge. It was different from some experts in defining knowledge. Al-Attas for example positioned Islam as a method in re-structuralization of science. (Islamization science). Fazlur Rahman positioned Islam as ethical, axiology values (Etico Religious), while Al-Ghazali positioned Islam as consciousness instrument which was placed in the human heart.

In this position, the Qur'an does not state that absolute truth belongs to a certain group such as the ulama community. Religious authority in The Qur'an rests on the truth brought by Islam. Thus, the ulama are not people who have broad truth authority. The duty of ulama is to arrange Islamic knowledge so that it becomes truth-structured. So that the truth is used for all humans in their worldview.

\section{References}

\section{Books}

al-Attas, Syed Muhammad Naquib, Islam and Secularism (Kuala Lumpur: ISTAC, 2003) Prolegomena to the Metaphysics of Islam (Kuala Lumpur: International Institute of Islamic Thought and Civilization, 1995)

, 'Risalah untuk Kaum Muslimin', in Himpunan Risalab (Kuala Lumpur: International Institute of Islamic Thought and Civilization, 2015)

, Risalah untuk Kaum Muslimin (Kuala Lumpur: ISTAC, 2001)

\section{The Concept of Education in Islam} (Petaling Jaya: ABIM, 1980)

Al-Khamis, Utsman Ibn Muhammad, Hiqbah min al-Tarikh, Cet. I, (Cairo: Maktabah alIslamiyah, 1999) 
Boeve, Lieven, Hans Geybels, and Stijn Van den Bossche, Encountering Transcendence: Contributions to a Theology of Christian Religious Experience (UK: Peeters Publishers, 2005)

Hadri, Hasan, Hidayah dalam Perspektif AlQur'an (Jambi: Sulthan Thaha Press IAIN STS Jambi, 2009)

Hamid, Rajih Abd, Nazariyah al-Ma'rifah bayna al-Qur'an wa al-Filsafah (Riyadh: Maktabah Al-Muayyad, 1996)

Husaini, Hussein, Qasas al- Qur'an: Muqtabas min Tafsir al-Amthal (Qum: Maktabah Anshariyan Publishing and Press, tt)

Khaldun, Ibn, Muqaddimah (Beirut: Dar alFikr, 1973)

Khatab, Sayed, The Political Thought of Sayyid Qutb: The Theory of Jabiliyyah (Cairo: alMaktabah, 2006)<https://doi.org/10.4324/9780203 086438>

Leaman, Oliver, 'Islam', in The Routledge Companion to Theism (UK: Routledge, 2012)

$<$ https://doi.org/10.4324/97802031232 94>

Ma'luf, Louis, Al-Munjid fi al-Lughah wa alA'lam (Beirut: Dar al-Masyriq, 1986)

Mustaqim, Abdul, 'Epistemologi Tafsir Kontemporer: Studi Komparatif antara Fazlur Rahman dan Muhammad Syahrur', \{unpublished doctoral thesis, UIN Sunan Kalijaga, Yogyakarta, 2007\}

Murphy, Wallace, What Islam Did for Us: Understanding Islam's Contribution to Western Civilization (London: Watkins Publishing, 2006)

Taba'taba'i. Thaba, Al-Mizan fi Tafsir al-Qur'an (Bairut: Muassasah al 'A'Lamy lil Mathbu'at, 1991)

Tim, 'The Oxford Dictionary of Islam', Choice Reviews Online, (UK: Oxford University Press, 2004)

Wan Daud, Wan Mohd Nor, 'Falsafah dan Amalan Pendidikan Islam', in Suatu Huraian Konsep Asli Islamisasi (Kuala
Lumpur: Penerbit Universiti Malaya, 1995)

\section{Journals}

Affani, Syukron, 'Rekonstruksi Kisah Nabi Musa dalam al-Quran: Studi Perbandingan dengan Perjanjian Lama', Al-Ihkam: Jurnal Hukum \& Pranata Sosial, 12.1

$123<$ https://doi.org/10.19105/alihkam.v12i1.1259>

Ahyar, Muzayyin, and Alfitri Alfitri, 'Aksi Bela Islam: Islamic Clicktivism and the New Authority of Religious Propaganda in the Millennial Age in Indonesia', Indonesian Journal of Islam and Muslim Societies, 9.1 (2019), $<$ https://doi.org/10.18326/ijims.v9i1.129>

Amir, H. M., 'Kisah Nabi Ibrahim dalam alQur'an dan Relevansinya dengan Pendidikan Islam', Ekspose, 23 (2014), 122

Effendi, Effendi, 'Historisitas Kisah Fir'aun dalam Perspektif Islam', Al-Adyan: Jurnal Studi Lintas Agama, 13. 1 (2018), 29-44 <https://doi.org/10.24042/ajsla.v13i1.2 944>

Elkarimah, Mia Fitriah, 'Kajian Asinonimitas al-Kitab wal al-Qur'an: Qira'ah Muashirah', Lingua: Journal of Language, Literature and Teaching, 14. 2 (2017), 302 $<$ https://doi.org/10.30957/lingua.v14i2. $302>$

Faisol, M., 'Struktur Nalar Arab-Islam Menurut Abid al-Jabiri', Tsaqafah, 6.2 (2010), <https://doi.org/10.21111/tsaqafah.v6i $2.124>$

Farida, Umma, and Abdurrohman Kasdi, 'The 2017 KUPI Congress and Indonesian Female "Ulama", Journal of Indonesian Islam, $\quad 12.2 \quad$ (2018), 135-158 <https://doi.org/10.15642/jiis.2018.12.2 $.135-158>$

Flanagan, Owen, 'Virtue and Ignorance', The Journal of Philosophy, 87.8 (1990), 420<https://doi.org/10.2307/2026736> 
Gaffar, Abdul, 'Kontekstualitas Makna Thaghut dalam Penafsiran al-Qur'an', Tajdid, 9.2 (2015),1-12

Hasan, Amin, 'Menyusuri Hakikat Kebenaran: Kajian Epistemologi atas Konsep Intuisi dalam Tasawuf al-Ghazali', Jurnal atTa'dib, 7 (2012), 189-203

Hasan, Hadri, and D I Ansusa Putra, 'The 2005th Amman Message: Significant Reference for Nusantara Ulama to Enlarge the Existing Indonesian Plurality', Millati: Journal of Islamic Studies and Humanities, 3.2 (2018), 173-188 $<$ https://doi.org/10.18326/mlt.v3i2.173 $-188>$

Hujair A H, Sanaky, 'Metode Tafsir [ Perkembangan Metode Tafsir Mengikuti Warna atau Corak Mufassirin ]', AlMawarid, 12.1 (2008), 1-12

Kania, Dinar Dewi, 'Konsep Virtue Ethics dalam Pemikiran Syed Muhammad Naquib Al-Attas dan Tantangan Postmodernisme', Tasfiyah, 1 (2017), 157 $<$ https://doi.org/10.21111/tasfiyah.v1i2. $1850>$

Karim, Abdul, 'Reformulasi Tafsir Ijtima'i dalam Menjawab Problematika Sosial', Hermeneutik, 9. 2 (2015), 419

Makhfud, Makhfud, 'Urgensi Tafsir Maudhu i (Kajian Metodologis)', Jurnal Pemikiran Keislaman, $27.1 \quad$ (2017), 25 $<$ https://doi.org/10.33367/tribakti.v27i $1.256>$

Maraimbang, M, Syahrin Harahap, and Amroeni Drajat, 'Ethics of Religion According to Fazlur Rahman', Journal of Humanities and Social Science, 24 (2019), 73-80

Mohamad Kamil Hj Ab Majid, 'Masyarakat Jahiliyyah vs Masyarakat Islam', Al-Bayan Journal of al-Quran \& al-Hadith, 16. 1 (2004), 18-30 <https://doi.org/10.1017/CBO9781107 415324.004>

Mustofa, Imron, 'Ulama' dan Kontestasi Pengetahuan dalam Sudut Pandang al Qur'ān', Jurnal Pendidikan Agama Islam
(Journal of Islamic Education Studies), 5. 1 (2017),

$<$ https://doi.org/10.15642/jpai.2017.5.1 $.68-93>$

Obermann, Julian, 'Koran and Agada: The Events at Mount Sinai', The American Journal of Semitic Languages and Literatures, 58. 1 (1941), 23-48 <https://doi.org/10.1086/370587>

Peels, Rik, and Martijn Blaauw, 'The Epistemic Dimensions of Ignorance', in The Epistemic Dimensions of Ignorance (New York: Oxford University Press, 2016), p. $1-217$

$<$ https://doi.org/10.1017/97805118200 $76>$

Romziana, Luthviyah, 'Pandangan al-Qur'an Tentang Makna Jâhilîyah Perspektif Semantik', Mutawatir, 4.1 (2015), 117-138 $<$ https://doi.org/10.15642/mutawatir.20 14.4.1.117-138>

Ropi, Ismatu, “Al-Yahūd fì Mu'allafāt alMuslimīn bi Indonesia: Dirāsah Awwalīyah', Studia Islamika, 26.1(2019), 149-183

$<$ https://doi.org/10.15408/sdi.v26i1.106 $31>$

Suarni, 'Pembaharuan Pemikiran Keagamaan: Studi Terhadap Pemikiran Keagamaan Fazlur Rahman', Substantia, 18 (2016), 206

Ulya, Ulya, 'Post-Truth, Hoax, dan Religiusitas di Media Sosial', Fikrah, 6.2 (2018) $283<$ https://doi.org/10.21043/fikrah.v6 i2.4070>

Yusuf, Muhammad Yunan, 'Metode Penafsiran al-Qur'an', Syamil, 2 (2014), 11 